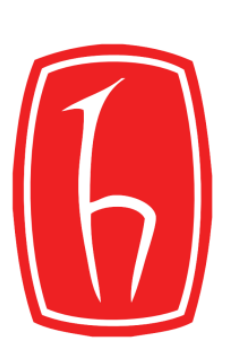

Hacettepe Üniversitesi Edebiyat Fakültesi Dergisi

Hacettepe University Journal of Faculty of Letters

Haziran/June 2021 - 38(1), 149-163

doi:10.32600/huefd.754273

Hakemli Makaleler - Refereed Articles

Geliş Tarihi / Received: 17.06.2020 Kabul Tarihi/Accepted:23.01.2021

\title{
Türk Halk Müziğinin Yeşilçam'daki Uygulaması ve Müzik Direktörü Ahmet Yamacı
}

\author{
Turkish Folk Music's Application in Yeşilçam and Director Music Ahmet Yamacı
}

\author{
Eray ALPYILDIZ*
}

Öz

İstanbul'da film şirketlerinin bulunduğu Beyoğlu'ndaki sokaktan adını alan Yeşilçam, Türk sinemasının özgün sembolik bir ismidir. Adı anıldığı zaman siyah beyaz görüntüleriyle nostaljik çağrışımların ortaya çıktı̆̆ 1 ve usta oyuncuların hatırlandığı Yeşilçam edebiyat, müzik, tarih, gelenek-görenek, halk inancı, mizah gibi unsurlarıyla araştırılması gereken bir alandır. Saydığımız bu alanlar içerisinde bugüne kadar Yeşilçam sinemasında Türk halk müziğinin yeterince incelenmediği görülmüş̧ür. Sessiz film döneminde sahne gerisine gizlenen bir piyanoyla ya da orkestralarla sesli hale getirilmeye çalışılan filmlerin, sesli sinema döneminden sonra amaç ve işlevleri çeşitlenmiştir. Ses ve görüntü kaydı alanındaki teknolojik gelişmelerin sinema sektörünü etkilediği ve biçimlendirdiği bir dönemde film müziği olgusu ortaya çıkmıştır. Film müziği, sinema tekniklerinin gelişmeye başladığı bir süreç içerisinde tekno-kültürel zeminlerde önemli işlevler yerine getirmiştir. Sinema sanatı içerisinde asli bir unsur haline gelen film müzikleri, filme seçilen ve yerleştirilen müzik parçaları ile filme özgü bestelenen ezgi/ezgiler şeklinde başlıca iki uygulama şekli bulmuştur.

Türkiye'de 1940'lı yıllardan itibaren köye yöneliş hareketinin başlamasının bir sonucu olarak yapılan çalışmaların bir ayağını da sinema oluşturmuş; bu doğrultuda Türk sinemasında köy temalı filmlerde müzik unsuru olarak halk müziğinin kullanımına başlanmıştır. Tekno-kültürel açıdan bağlam bütünlüğünün sağlanmasında bir gereklilik de olan bu uygulamayı -söz konusu filmlere- gerçekleştiren kişiler, radyo ekolünden gelen halk müziği yöneticileri ve müzisyenleri/sanatçıları olmuştur. Bu bağlamda makalede film müziği, film müziğinin işlevleri, film müziği ve filmde müzik kavramlarının farkı, Yeşilçam sineması içerisinde film müziğinin kullanımı, halk müziği ve Yeşilçam ilişkisi incelenmiş; radyonun halk müziği şeflerinden ve saz sanatçılarından olan Ahmet Yamacı'nın müzik direktörlüğü örneğinden hareketle Türk sineması ve Türk radyo yayıncıllı̆g arasındaki ilişki halk müziği temelinde sorgulanmiştır.

Anahtar sözcükler: Yeşilçam, Film müziği, Radyo, Türk halk müziği, Sinema.

\begin{abstract}
Yeşilçam, named after the street in Beyoğlu where movie companies are located in İstanbul, is a unique symbolic name of Turkish cinema. Yeşilçam, where nostalgic associations emerge with its black and white images when its name is mentioned, and master actors are remembered, is a field that needs to be studied with its components such as literature, music, history, tradition-custom, folk belief and humour. Among the areas that have been mentioned, it has been observed that Turkish folk music has not been sufficiently studied in Yeşilçam cinema. In the silent film period,
\end{abstract}

*Doktora Öğrencisi, Hacettepe Üniversitesi, Edebiyat Fakültesi, Türk Halkbilimi Bölümü.

E-posta: erayalpyildiz@gmail.com, ORCID: 0000-0002-8967-4612 
the purposes and functions of the films, which were tried to be made vocal with a piano or orchestras hidden behind the scenes, varied after the sound cinema period. The phenomenon of film music emerged at a time when technological developments in the field of sound and image recording affected and shaped the cinema industry. Film music has fulfilled important functions on techno-cultural grounds in the course of the developments seen in the cinema technologies. The soundtrack, which has become an essential element in the art of cinema, has found two main application forms: the music pieces selected and placed in the film and the melodies composed specific to the film.

Since 1940s, in Turkey, cinema has formed one of the components of the works done as a result of the orientation towards the village movement. Accordingly, folk music has been used as a musical element in village-themed films in Turkish cinema. In forming the integrity of this techno-cultural phenomenon, the people who carried out this practice were the folk music managers and musicians/artists from the radio. In this context, film music, the functions of film music, the difference of soundtrack and music concepts in film, the use of film music in Yeşilçam cinema, the relationship between folk music and Yeşilçam are examined in the article. Moreover, the relationship between Turkish cinema and Turkish radio broadcasting has been questioned on the basis of folk music, based on the example of Ahmet Yamacı's music director, one of the folk music chiefs and instrumentalists of the radio.

Keywords: Yeşilçam, Film music, Radio, Folk music, Cinema.

\section{Giriş}

Müziğin teknoloji ile ifadesinde fonograf, gramofon, radyo, sinema, televizyon, plak, kaset, cd-dvd, mp3, internet gibi çeşitli araçlar/platformlar tarihsel süreç içerisinde kendi icra bağlamlarını yaratarak her türlü (sosyal, ekonomik, kültürel) üretim, tüketim, aktarım ve dönüşümün tekno-kültürel zeminlerde yaşanmasına neden olmuştur. Türkiye'de folklor araştırmaları temelinde yürütülen halk kültürüne yöneliş hareketinde halk müziği ile teknoloji ilişkisi (araç, yöntem, bilgi, süreç vb.) ise bazı kavşaklarda bir araya gelmiştir. Örneğin -işlevleri çeşitlense de- derleme çalışmaları sürecinde kaynak kişilerin performanslarını kaydetmek için fonograf ve gramafon; derlenen materyalin kültürel ekonomik bir ürüne dönüştürülmesinde plaklar; yine bu materyalin -uygulamalı bir halkbilimi göstergesi olarak yorumlanabilecek- yeniden inşası ve icrası açısından radyo, teknoloji ile kültürün halk müziği özelindeki ilk dönem faaliyetleri arasında olmuştur. Halk müziği ile teknoloji ilişkisinin çok yönlü sürecinde radyodan sonraki önemli bir basamak ise sinemadir.

Türk toplumunun Beyaz Perde ile tanışması halk müziği, halk tiyatrosu, halk edebiyatı gibi alanlara farklı işlevler yüklemiş̧tir. Geleneğin ve ustalarının icra bağlamının değiştiği/çeşitlendiği bir görsel-işitsel bir kültür ortamı olan sinema, işitsel temelli başka kültür ortamı olan radyoyla sıkı ilişki içerisinde bulunmuştur. Türkiye'de radyo yayıncılığının başlangıcından sonra radyoda halk kültürü unsurlarına yer verilerek bu yeni elektronik kültür ortamının halk tarafından seçkin bir kesime hitap ettiği algısının önlenmesine dair uygulanan yöntemin bir diğeri de sinema türünde yaşanmıştır. Başka bir deyişle cumhuriyetin kültür politikaları doğrultusunda halk müziği başta olmak üzere halk kültürü olanca varlığıyla teknolojik araçların içerisinde çeşitli amaçlarla (örneğin ulusal kimliği/belleği pekiştirme) temsil edilmiştir. Bu doğrultuda 1940 ve 1950'li yılların köye dönüş hareketiyle birlikte kırsalın beyaz perdeye yansıtıldığı bir ortamda yerel ağızlar, gelenek ve görenekler, argo ve küfürler, halk inançları ve oyunları vb. unsurlar sinema filmlerinde koltuk kapmakla birlikte halk müziği de filmlerde müzik unsuru olarak kullanılmaya başlanmıştır. Burada dikkat çeken bir nokta ise -ilerde çözümleyeceğimiz gibi- halk müziğinin, Yeşilçam'da radyonun dağarcığı ve Yurttan Sesler modeli bağlamında yer bulmasıdır. Bu bağlamda radyonun halk müziği şahsiyetleri, sinema alanında müzik direktörlüğü görevini üstlenmişler ve radyonun halk müziği anlayışını (çalış, söyleyiş, topluluk, repertuar) sinemaya taşımışlardır. İlk olarak Muzaffer Sarıözen'le sistemli olarak başlayan bu süreç, onun öğrencilerinden ve Yurttan Sesler Korosu'nun önemli saz sanatçılarından Ahmet Yamacı tarafindan sürdürülmüştür. Türk sinema tarihinde müzik direktörü kimliğiyle yer bulan A. Yamacı, 1964 yılında Berlin Film Festivali’nde birincilik ödülü kazanan Susuz Yaz'in ve Kemal Sunal'ın meşhur Kibar Feyzo adlı filminin müziklerini seçmesiyle dikkatleri çekmiştir. M. Sarısözen tarafından sinemaya aktarılan Yurttan Sesler modelinin ilerleyen süreçlerde başka isimler tarafından uygulama şekillerini gözlemleyebilme/çözümleyebilmeadına da önemli bir kişi olan A. Yamacı'nın bugüne kadar çalışılmaması bir eksiklik olarak karşımıza çıkmıştır. 
Bütüncül bir ifadeyle Türk halk müziği ile sinema ilişkisinin yeterince araştırılmadığı ve çözümlenmediği gerçeğinden hareketle bu çalışma, belirlenen kapsamlarla çeşitli konulara temas etme, dikkat çekme ve alandaki boşluğu bazı yönleriyle kapatma amacı taşımaktadır.

Bu bağlamda M. Sarısözen tarafindan radyodan sinemaya açılan çığır temel alınarak A. Yamacı'nın müzik direktörlüğünü üstlendiği bazı filmlerle (genellikle 1950-1960'lı yıllar ile) sınırlandırılan bu çalışmada film müziği ve bu müziğin işlevleri belirtilerek halk müziğinin sinemada film müziği mi yoksa filmde müzik unsuru mu olduğu çözümlenecek; radyonun halk müziği modelinin sinemaya nasıl yansıdığ irdelenecek; Ahmet Yamacı'nın müzik direktörlüğü yaptı̆̆ı birkaç film ezgi, sahne seçimi, çalgı türleri, icra şekilleri açısından analiz edilecektir.

\section{Film Müziği ve Film Müziğinin İşlevleri}

Sinemanın teknolojik gelişim aşamaları ve film türlerine göre çeşitli film müziği tanımları yapılmıştır. Paul Tonks'a göre (2006) film müziği "gösterilen filmdeki teatral hareketleri desteklemek için kullanılan müzik"tir (s. 9). Daha bütüncül bir tanıma göre ise film müziği "çevrilen filmin temasına ya da belirli sahnelerine göre görüntüyü destekleyici nitelik ve uyumda bestelenen ya da düzenlenen müziğe denir" (Erdoğan ve Beşevli Solmaz, 2005, s. 55).

Konuralp'e göre (2004) dünyada film müziğinin tarihsel gelişimi üç döneme ayrılmaktadır.

a. Sinematografin icadına kadar müzik eşliğinde hareketli görüntü gösterimlerinin yapıldığ 1 Arkeolojik Sinema Dönemi,

b. Sinematografin icadından sonra sesin henüz kullanılmadığı ancak gösterimlere salonda haricen çalınan müziğin eşlik ettiği Sessiz Sinema Dönemi

c. Sinemaya sesin girmesinden başlayarak günümüze kadar giden Sesli Dönem. (Doğan, 2009, s. 94).

Tarihsel ve yöntem olarak başka bir film müziği sınıflandırması ise şu şekildedir (Akgün, 2009, s. 36-38): “a. Sessiz Sinema Döneminde: Çekim Sırasında Müzik, Gösterim Sırasında Müzik; b. Sesli Sinema Döneminde: Görüntüye Göre Hazırlanmış Senkron Müzik, Müziğe Göre Hazırlanmış Senkron Görüntü, Filme Göre Müzik”.

Sessiz sinema dönemindeki filmlerde ilk müzik kullanımı, filmin çekildiği mekâna gelen çeşitli müzisyenlerin/orkestraların filmin heyecanl1, dramatik ve romantik sahnelerinde oyuncuları motive etmek için gerçekleştirdiği icralar şeklindedir. (Akgün, 2009, s. 36). Bu dönemde uygulanan ikinci yöntem ise "film makinesinin gürültüsünü bastırma, eski karanlık salonların insan üzerinde bıraktığı huzursuzluğa engel olma" (Dalgın, 2011, s. 17), seyirciyi filmin içine çekme ve sessizliği yırtma gibi teknik ve ruhsal boyutuyla önem kazanan sahne ardındaki canlı müzik icralarıdır.

Sesli sinema döneminde ise birinci olarak filmin çekimi bitip montajı yapıldıktan sonra sahnesiyle bütünlük sağlamak için uyarlanan eş zamanlı (senkron) müzik; ikinci olarak filmden bağımsız bir şekilde hazırlanan müziği resmetmek anlamına gelen serbest görüntü uygulaması (örneğin müzikaller ya da Türk sinemasında Orhan Gencebay filmleri vb.); üçüncüsü ise filmin senaryo aşamasından itibaren ele alınan unsurlarıyla müziğin bestelenip filmle kaynaştırılması ve anlatımın desteklenmesi başlıca yöntemlerdir (Akgün, 2009, s. 36-38).

Genel olarak değerlendirildiğinde ise film müziğinin çeşitli işlevleri bulunmaktadır. Tony Thomas'a göre film müziği "atmosferi yaratır" (konunun geçtiği coğrafik ya da tarihi alanın, zamanın, yaşayışın hikâye edilenin durumları) ve "resmin renk tonudur"(güçlü ya da zayıf bir etkiyi belirtmek için karakter çözümlemesi yapmak veya tansiyonu belirlemek). Pudovkin'e göre ise film müziğinin amac1 "nesnel olarak algılanan görüntünün, öznel değerlendirilmesini sağlamaktır” (Erdoğan ve Beşevli Solmaz, 2005, s. 60). Amerikalı besteci Aaron Copland ise "film müziği, sinema perdesinin arkasına yerleştirilmiş bir firına benzer. Filmin sıcaklığı oradan gelir" (Konuralp, 2004, s. 17) şeklinde duygusal bir tanımlama yapmıştır.

Film müziğinin işlevleri konusunda Paul Hartley ise şunları söylemiştir: 
Sosyokültürel sunumun gerçekliğini tamamlayacak ya da zayıflatacak ek sembolik bir katman olarak hareket eder ve yeni ilişkileri yaratır ya da birleştirir. Film müziğinin iktidarı ve söyleme gücü, buna bağlı olarak akışkanlığa ve açıklığa izin verir. Film müziği böylelikle hem paylaşılan sosyo-kültürel gerçekler kümesinin semptomatik hem de yaratıcı bağlantılar olsa da yeni sosyokültürel anlam yaratan mekanizmada önemli bir lokomotiftir. (Hartley, 2012, s. 2-3)

Tanımlamalarda dikkat çekmemiz gereken bir nokta ise film müziği ile filmde müzik adlandırmalarının farklı kavramlar olduğudur. Bu bağlamda "film müziğini, filmdeki anlatı akışı sırasında aktörün veya aktristin söylediği şarkıyla/türküyle karıştırmamak gerektiği; bu tür müzik uygulamasının filmde öykünün akışında bir yere yerleştirilmiş ve öykünün dizinsel (kurgusal) anlatımının bir parçası olarak kullanıldığı" belirtilmektedir. (akt: Erdoğan ve Beşevli Solmaz, 2005, s. 55).

Türk sinemasında özgün film müziği bestelerinin yerine plak arşivinden müzik sağlanılması on yıllar boyunca uygulanan yöntemlerin başını çekmiştir. Bu hususta Konuralp (2004, s. 63-66) Nedim Otyam'ın türettiğini ve Yeşilçam'da müzik döşemeciliği olarak adlandırdığını belirttiği bu sistemin 1980'li yılların sonuna kadar kullanıldığını; Türk filmlerinin yaklaşık \%90'ının bu şekilde oluşturulduğunu; ilk uygulamaları klasik, caz ve hafif müzik türleriyle başlayan müzik döşemeciliğinin bazı filmlerin türlerine göre branşlaşmalar gerektirdiğini; bu bağlamda köy filmlerindeki halk müziği kullanımında Muzaffer Sarısözen ve Sadi Yaver Ataman, Türk müziğinde Muhittin Sadak ve Mesut Cemil Tel, klasik müzikte Faruk Yener, hafif Batı ve caz müziğinde Sezen Cumhur Önal ve Fecri Ebcioğlu'dan yararlanıldığını; bu uygulamaların görüntü ve müzik ilişkisi açısından değerlendirilmesi gerektiğini; Türkiye'de sinema endüstrisinin oluşmaması nedeniyle uzun yıllar bu yöntemin varlığını koruduğunu dile getirmiştir.

$\mathrm{Bu}$ bağlamda Yeşilçam sineması içerisinde halk müziği, uygulanış itibariyle film müziği (soundtrack) olarak değil filmde müzik şeklinde yer bulmuştur. Bununla beraber filmler içerisine döşeme yoluyla halk müziği ezgileri yerleştiren kişiler için ise film müziği yapan yerine filmin müziklerini seçen ifadeleri daha doğru bir kullanım olacaktır. Diğer taraftan alanda yapılan çalışmaların çoğunda sinema ve müzik ilişkisi içerisinde film müziği kavramı, sessiz film dönemindeki müzik kullanımlarından günümüze kadar uzanan bir süreçte bütünü kapsayacak bir şekilde genel kabul görmüş, ifade alanı bulmuş ve tarihsel sınıflandırmalar da bu kavram altında yapılmıştır. Özetle, dünya sinema tarihinde sessiz film döneminde perde ardına gizlenen piyanoyla canlı icra edilen ya da gramofon aracılığıly sessizlik perdesinin kaldırılması şekliyle filmlerde yer verilen müzik, sesli sinema döneminde ses- kayıt teknolojilerinin gelişmesiyle de birlikte farklı biçimler ve içerikler kazanmış,"soundtrack"1 denilen noktaya evrilmiştir.

\section{Türk Sinemasında Film Müziğinin Tarihçesi}

Türkiye'ye sinemanın gelişi -radyo örneğinde olduğu gibi- Avrupa'yla yakın zamanlı olmuştur. Paris'te ilk sinematograf gösterimi yapan Lumiere Kardeşlerin operatörlerinden Alexandre Promio, 1896 'da İstanbul'a gelmiş ve padişahtan izin alarak İstanbul ve İzmir çevresinde çeşitli belgesel filmler çekmiştir. İlk sinema filmini saray çevresine Fransız taklitçi ve hokkabaz Bertrand izletmiş; halka açık ilk sinema filmi ise 1897'de Galatasaray Lisesi'nin karşısında bulunan Sponeck Birahanesi'nde Sigmund Weinberg tarafından gösterime sunulmuştur. İstanbul'daki ilk yerleşik sinema salonu 1908 yılında Darülbedayi'nin Komedi Bölümü'nün içine açılmıştır. İlk Türk filmi olarak bazı kaynaklar Manaki Kardeşler'in 1911 yılında Sultan Reşat'ı çektikleri filmi, bazıları da Fuat Uzkınay'ın 14 Kasım 1914'de Ayastefanos'taki Rus Abidesi'nin Yıkılışı adlı filmi göstermektedir. (Özdemir, 2008, s. 163. Ayrıca bakınız: Özön, 1968, s. 43-44; 1983, s. 1878-1879; 1995, s. 18-19).

Türkiye'de film müziğinin gelişim tarihi beş ayrı dönemde ele alınmıştır (Konuralp, 2004, s. 59):

\footnotetext{
1"Bir filmin sesinin film üzerine kaydedildiği yer" (Erdoğan ve Beşevli Solmaz, 2005, s. 56); “film için yapılmış, kaydedilmiş ve filmle beraber çalınmış müzik" (Akgün, 2009, s. 18).
} 
1. Sessiz Film Dönemi (1897-1931)

2. Şarkılı Melodram ve Operet Dönemi (1931-1938)

3. Yeniden Skorlama Dönemi (1938-1950)

4. Sinemac1lar Dönemi (1950-1960)

5. 1960-1990 Dönemi

Türkiye'de Sessiz Film Döneminde Beyoğlu'ndaki sinemalarda çekirdek çıtırtıları arasında gayrimüslim kadınlar tarafından çalınan piyanoların yanı sıra çeşitli opera sinemalarında önemli yabancı orkestra şefleri icralarda bulunmuş; İstanbul dışında İzmir'de Elhamra'da (Milli Sinema) sessiz filmlerin müziklerini Mümtaz Uygun çalmış; cumhuriyetin ilanından sonra Ankara'da ise Basri Bey adlı bir kişi Ulus Sineması'nda sessiz film piyanistliği yapmıştır. Diğer taraftan çeşitli Açıkhava Sinemalarındaki gösterimlerde de müzik ihmal edilmemiştir. Örneğin Kamer Sineması'nın 1914 yılında yayınlandığı sanılan bir el ilanında Örümcek A $\breve{g}$ filmine "kemani-i şehir bülbüli Salih Efendi mahdumu Selahattin Efendi'nin incesaz takımı tarafından fasıllar ve mükemmel orkestranın eşlik ettiğiı"nin yazıldığı; Aşk-ı Sevda ve Kerametli Düdük adlı filmlerin ilanında ise sekiz kişilik mükemmel ince saz şeklindeki bir ifadeyle sinema orkestrasının tanıtıldığı belirtilmektedir. Bu dönemde Pençe, Casus, Himmet Ă̆a'nın İzdivacl, Mürebbiye, Binnaz, Bican Efendi gibi Türk filmleri çekilmesine karşın bunların bestesi yapılmamıştır. Bu yıllarda gösterime giren Türk filmlerinin nasıl bir müzik anlayışı olduğu sorusu ise Muhsin Ertuğrul'un 1922'de çektiği Boğaziçi Esrarı filmi incelenerek yanıtlandırılabilir. Film için hazırlanan bir ilanda Yeni Milli Sinema'da sunulacak olan filme Büyük Alaturka Salon Orkestrası'nın eşlik edeceği ve Türk eserlerinin çalınacağı ifade edilmiştir. Bununla beraber Muhsin Ertuğrul'un Leblebici Horhor A $\breve{g} a$ adlı diğer filminde de aynı adlı sahne oyununun müzikleri orkestra tarafindan çalınmıştır. (Konuralp, 2004, s. 60-63).

Türkiye'de sesli film yapımına ise 1931 yılında başlanabilmiştir. Şarkılı Melodram ve Operet Dönemi olarak adlandırılan bu evrede İpek Film tarafından Muhsin Ertuğrul'un yönetmenliğinde Türk sinemasının ilk sesli filmi İstanbul Sokakları (1931) çekilmiştir. Hasan Ferit Alnar ve Hüseyin Sadettin Arel'in çeşitli şark1 ve tangolar düzenleyerek bunları yerleştirdikleri filmde Ekin Ektim Çöllere ve Zeynebim türküleri ile Yum Güzel Gözlerini Sevgili Yavrum, Uyu adlı bir ninni seslendirilmiştir. Bu doğrultuda ilk sesli Türk filmi ilk şarkılı melodram olmuş; Batı'dan müzik, Doğu'dan seçilen melodram türüyle bir senteze gidilmiştir. 1930'lu yılların tek film yönetmeni Muhsin Ertuğrul Karım Beni Aldatırsa, Söz Bir Allah Bir, Cici Berber, Tosun Paşa gibi filmlerle operet film tarzına yönelmiştir. Muhsin Ertuğrul, yönettiği filmlerde türkü söyletme geleneğini sürdürmüş; dönemin ünlü plak şirketi Sahibinin Sesi'nin arşivinden seçtiği ezgileri filmlere yerleştirerek döşeme geleneğini başlatmıştır. Bir Millet Uyanıyor (1932) filmi, bu uygulamanın ilk örneğidir. ${ }^{2}$ Diğer taraftan Aysel Bataklı Damın Kızı (1934) adlı filmin müziklerini Cemal Reşit Rey’e yaptırarak başka bir tarz denemiştir. (Konuralp, 2004, s. 64-68). Film için bestelenen ezgilere sonradan Dök Zülfünü Meydana Gel adlı şarkı ile Atım Kaçtı Ben Vuruldum, Harmandalı Zeybeği ve Tamzara'da Vuruldum Ta Köyecek Duyuldum adlı türkü ve ezgiler eklenmiştir. (Onaran, 1981, s. 242). Geleneksel Türk müziği çalgılarının kullanıldığı bu film, Türk sinemasında konusu itibariyle köyü işleyen ilk film olma özelliği taşımaktadır. 1939'da çekilen Allah'ın Cenneti adlı film ise Türk sinemasına şarkıcı-oyuncu türünü getirmiş ve Münir Nurettin Selçuk'u beyazperdeye taşımışıtır (Erdoğan ve Beşevli Solmaz, 2005, s.107).

İkinci Dünya Savaşı'nın mali etkilerinin yansıdığı dönemde ise Amerika'dan film ithalatının zorlaşması nedeniyle Lale Film gibi şirketlerin Mısır melodram filmlerini getirdikleri görülmüştür. Arap müziği içeren bu filmlerin özgün halinin Türkiye'de yayınlanmasının yasak oluşu nedeniyle Sadettin

\footnotetext{
${ }^{2}$ Bu filmde Sahibinin Sesi'nden seçilen plaklarla Bir Gemim Var Adalara Yaslanır ve At Martini Debreli Hasan adlı türküler filme yerleştirilmiştir. (Onaran, 1981, s. 204-205).

${ }^{3}$ Alim Şerif Onaran'a göre bu film, "Türk köy filmlerinin ilk örneği veya prototipidir” (1981, s. 242). Özgüç’e göre (2005) "köy filmlerinin tarihçesi 1934 yılında başlar ve bu türün ilk yönetmeni Muhsin Ertuğrul'dur" (s. 125).

Özön'e göre bu film "M. Ertuğrul'un en iyi çalışmaları arasındadır" (1995, s. 24).Bu filmle ilgili başka bilgi ve eleştiriler için bakınız: Scognamillo, 2003, s. 59-62; Özgüç, 2005, s. 45.
} 
Kaynak ve Münir Nurettin Selçuk gibi müzisyenlerden bu filmlerin -yeniden skorlama ${ }^{4}$ olarak tabir edilen bir yöntemle- müziklerinin yapılması istenmiştir. $\mathrm{Bu}$ doğrultuda ilerde Hint filmlerinin getirtilmesine kadar genişleyecek bu yöntem nedeniyle Artaki Candan, Sadi Işılay, Şerif İçli, Şükrü Tunar, Kadri Şençalar, Hüseyin Coşkuner, Mustafa Nafiz Irmak, Selahattin Pınar gibi bir müzisyen kadrosu film müzikleri alanında boy göstermeye başlamışlardır. (Konuralp, 2004, s. 68-70; Pekman, 2004, s. 31).

Türk sinemasında 1940'lı yıllar tiyatronun etkisinin yavaş yavaş azaldığı; M. Ertuğrul dışında yeni yönetmenlerin ortaya çıktığı; sinemanın kendi sesini bulmaya çalıştığı; köye yöneliş hareketi doğrultusunda köy filmlerinin çekildiğgi; filmlerin müziklerinde halk çalgıları ve halk müziğinin kullanılmaya başlandığ 1 bir dönem olmuştur. "1943'te Faruk Kenç, ilk köy filmi olan Dertli Pınar'1 çekmiş ve bu film gerçek köy dügünü, köy şarkıları ve kaşık oyunlarıyla gerçekçi folklorik olma iddiasını taşımıştır" (Scognamillo 1998'den akt: Erdoğan ve Beşevli Solmaz, 2005, s. 111). Bu dönemde Türk sinemasında, Ankara Radyosu Yurttan Sesler Korosu'nun şefi ve derlemeci Muzaffer Sarısözen'in müzik direktörlüğ̈̈ görevini yapmaya başlaması dikkatleri çekmiştir. 1946 yılında Muhsin Ertuğrul'un Kızılırmak Karakoyun adlı filminin müzikleri Muzaffer Sarısözen tarafından seçilmiştir. ${ }^{5}$

1950'li yıllar ise Türk sinemasının kimliğini bulmaya ve özgün film müziklerinin bestelenmeye başladığı bir dönem olmuştur. Bu dönemde Nedim Otyam ismi ön plana çıkmış; Otyam 1950'lerden itibaren Atlas Film bünyesinde müzik yönetmenliğini üstlenerek İstanbul'un Fethi (1951), Toprak, Yurda Dönüş filmlerinin müziklerini hazırlamıştır. (Konuralp, 2004, s. 64-68). Otyam “1950'lere kadar özgün Türk filmi müziği yoktu, çeşitli uygulamalar vardı. Onlar sinemada müzikti; sinema için yapılmış müzikler değildi" açıklamasında bulunmuştur. (Akt: Erdoğan ve Beşevli Solmaz, 2005, s. 112-113).

1952 yılında ise yönetmen Metin Erksan'ın ilk filmi olan Karanlık Dünya (Âş1k Veysel'in Hayatı) birçok yönüyle dikkat çekmektedir. Atlas Film bünyesinde çekilen, senaryosunu Bedri Rahmi Eyüboğlu'nun yazdığı, film müziklerini Orhan Barlas'ın seçtiği ve Ruhi Su'nun ilk kez bir türkü söylediği film, Âşık Veysel'in hayat hikâyesini işlemiştir. Biyografik-dram tarzında çekilen ve ilk gerçekçi köy filmi ${ }^{6}$ olan Karanlık Dünya, âşıklık geleneğin önemli bir temsilcisinin beyazperdede oyuncu (aktör) olarak görev aldığı ilk filmdir. Hayatındaki çeşitli olayların işlendiği, bazı türkülerinin seslendirildiği, çocukluk ve gençlik dönemlerinin başka aktörler tarafından oynandığı filmde Âşık Veysel, yalnızca filmin sonlarında kameranın karşısına geçmiş; filmde çok az yer bulan bazı diyaloglarına dublaj yapılmıştır. (https://www.youtube.com/watch?v=VtPY1AX7pSQ). (Ayrıca bakını: Özön, 1968, s. 26-27; Scognamillo, 1973a, s. 10; 1973c, s. 41; 2003, s. 144; Özgüç, 2005, s. 119-120, 288). "İlerleyen y1llarda âş1k biyografisi, halk hikâyesi, efsane, türkü hikâyesi veya başka bir geleneksel unsuru konu alarak çekilen filmlerin sayısı artmış; dolayısıyla bu filmlerin müziklerinde geleneksel müzik unsurları yerleştirilmiştir" (Fidan, 2017, s. 128).

1950'li yılların Türk filmi müziklerinde radyonun halk müziği temsilcilerinin belirgin izlerine rastlanmaktadır. Muzaffer Sarısözen ve Ahmet Yamacı'nın öne çıktığı bu filmlerde radyonun Yurttan Sesler modeli/geleneği sinemaya yansıtılmıştır. 1955 yılında Lütfi Akad'ın çektiği Beyaz Mendil filminin müziklerini Sarısözen seçmiştir. Bu filmin müzikleri için Akad şunları söylemiştir: “...Ayrıca Beyaz Mendil, folkloru da en saf haliyle ilk kez fon müziği olarak kullanan filmdir". 1956 yılında Ahmet Yamacı, Muammer Gürses tarafından çekilen Sazlı Damın Kahpesi adlı filmin müziklerini seçmiştir. Yine 1956 yılında Muzaffer Sarısözen, Atıf Yılmaz'ın çektiği Gelinin Muradı filminin müziklerinde görev sahibi olmuştur. 1958-59 yılında Atıf Yılmaz'ın Bu Vatanın Çocukları ${ }^{7}$ ve ünlü yönetmen Metin Erksan'ın Susuz Yaz adlı filmlerin müziklerini yine Ahmet Yamacı seçmiştir. Muzaffer Sarısözen ayrıca 1958 yılında Bu Vatan Bizimdir, 1959 yılında Tütün Zamanı ve Ala Geyik filmlerinde müzik direktörlüğü

\footnotetext{
${ }^{4}$ Score (Skor): Müzikte ayrı ayrı bütün çalgılara ve seslere ait notaların ayrı ayrı gösterildiği müzik parçası. Filmin skoru ile o film için yazılmış eser kastedilmektedir. (Konuralp 2004, s. 16).

${ }^{5}$ Ayrıntılı bilgi için bakınız: Onaran, 1981, s. 303-304; Alpyıldız, 2018, s. 287-289.

${ }^{6}$ Köy filmleriyle ilgili değerlendirmeler için ayrıca bakınız: Scognamillo, 1973a, 1973b, 1973c.

${ }^{7}$ Scognamillo'ya göre (2003) "Bu Vatanın Çocukları filmi Atıf Yılmaz için tür sınavını başarıyla geçtiği bir film olmuş; bu filmden sonra Alageyik ve Karacaoğlan'ın Kara Sevdası (1959) adlı iki folklorik çalışmaya girişmiştir. (s. 142-143).
} 
görevlerini üstlenmiştir. (Beşevli, 2002, s. 60, 67-68, 70; Alpyıldız, 2018, s. 287-296; http://www. sinematurk.com/kisi/3183-muzaffer-sarisozen/).

\section{Ahmet Yamacı'nın Biyografisi ve Yeşilçam'daki Görevleri}

1926'da Burdur'un Tefenni ilçesinde doğan Ahmet Yamac1, Ankara Radyosu Yurttan Sesler Korosu'nun çekirdek kadrosunun ilk saz sanatçılarındandır. Uzun yıllar Ankara Radyosu'nda Sarısözen'in şefliğinde görev yapan sanatçı, İstanbul Radyosu'nda kurulan halk müziği korosuna Muzaffer Sarısözen'in görevlendirmesiyle şef olarak atanmıştır. İlerleyen dönemlerde TRT'de Bilimsel Araştırma ve Repertuar Kurulu Üyeliği; TRT İstanbul Radyosu Türk Halk Müziği ve Oyunları Şube Müdürlüğü görevlerinde bulunmuştur. Emekli olduktan sonra da Halk Müziği ve Oyunları yarışmalarında jüri üyesi olarak görev yapan Yamac1, 21 Mart 1987 tarihinde İstanbul'da yaşamını yitirmiştir.

Türk halk müziği ve radyo yayıncılı̆̆ tarihinde önemli bir isim olan Ahmet Yamac1, araştırmalarımız sonucunda Türk sinemasında da varlığını hissettirmiş bir gelenek kültürü şahsiyeti olarak karşımıza çıkmaktadır. Türk sineması içerisinde çok sayıda filmin müzikleri Yamacı tarafından seçilmişolmasına karşılık onun bu yönü/niteliği araştırılmamıştır. Ayrıca Ahmet Yamacı, Türk sinemasında M. Sarısözen'in müzik direktörlüğünü yaptığı filmlere sazıyla katılmış; bazı filmlere de Ahmet Yamacı Saz Topluluğu adında oluşturduğu bir halk müziği grubuyla katkı sağlamıştır. Bu filmler hakkında şöyle bilgi verebiliriz:

a. Müzik Direktörlüğünü Üstlendiği Filmler: Sazlı Damın Kahpesi (1956), Yanık Kezban (1957), Kin (1957), Kahpe Kurşun (1957), Dertli Irmak (1958), Bu Vatanın Çocukları (1959), Kanundan Kaçılmaz (1959), Ateşli Kan (1962), Susuz Yaz (1963), Dağlar Bizimdir (1964), Kibar Feyzo (1978), Erkek Güzeli Sefil Bilo (1979).

b. Çalgısı veya Orkestrasıyla Görev Yaptığı Filmler: 1955 'te Beyaz Mendil (meydan sazı), 1956'da Yetimler Ahı (bağlama), 1957'de Gelinin Muradı (bağlama), 1958'de Mavi Boncuk (Ahmet Yamacı Saz Topluluğu), 1958'de Elveda, 1958'de Dokuz Dă̆ın Efesi (Yamacı İdaresinde Folklor Ekibi).

c. Solist Olarak veya Başka Görev Aldığ1 Filmler: 1957'de Ak Altın (türküler), 1958'de Tütüncü Kızı Emine (türküler), 1959’da Tütün Zamanı (Folklor Ekip Şefi), 1959’da Cilalı İbo Yıldızlar Arasında (türküler), 1959'da Çakır Eminem (türküler).

d. Oyuncu Olarak Rol Aldığı Film: Cilalı İbo Yıldızlar Arasında (1959). (Özgüç, 2012, s. 87, 91 93, 96, 99, 103-106, 138; http://www.tsa.org.tr/tr/kisi/kisi goster/1083/ahmet-yamaci).

\section{Seçilen Filmler Hakkında Bilgiler ve Müzikal Analizler}

Ahmet Yamacı'nın müzik direktörlügü yaptığı ilk film Sazlı Damın Kahpesi (1956)'dir. Muharrem Gürses yönettiği ve Özdemir Birsel de yapımcılığını üstlendiği filmin konusu genç yaşta dul kalmış çiftlik sahibi Muhteşem Hanım'ın, çiftliğinde çalışan genç yanaşma Ahmet'e gönül verip reddedilmesi üzerine Ahmet'i nişanlısıyla ayırma entrikalarıdır (http://www.sinematurk.com/film/5634-sazli-damin-kahpesi/).

Filmin jenerik müziğinde Çiçek Dăğ enstrümantal olarak çalınmaktadır. Dere kenarında çamaşır yıkama sahnesinde Suya Gider Su Testisi Elinde (kadınlar koro), Geline Bak Geline Kına Yakmış Eline (kadın solo icra); pınar başında Ahmet ve nişanlısının karşılaşmalarında enstrümantal olarak Karanfilim Budama, bir odada buluşmalarında İnce Giyerim İnce, annenin çocuğundan ayrılması sahnesinde Geceler Yarim Oldu, dere kenarında âşı̆̆ın sevdiğinin peşine düştüğü sahnede enstrümantal Karanfilim Budama, şehirdeki/kasabadaki bir lokalde sahnede oynayan bir dansöz görüntüsünde Adana'nın Yolları Taştan türküleri duyulmaktadır. Filmde dramatik unsurların ağır bastığı duygusal sahnelere divan sazıyla uzun hava açışları eşlik etmesine karşlık duygusal ve aksiyonlu anlara bazen de klasik Batı müziği orkestralarının sözsüz ezgileri damga vurmusstur. Bu sahnelere 32'lik ve 64'lük nota süre değerleriyle örülü ve metronomun hızlandığı çok sesli melodiler seçilmiştir. Başka bir deyişle kavga/dövüş, 
atlama/zıplama, yerde sürükleme, at sürme gibi aksiyonun ve gerilimin yükseldiği anlarda veya acıma/acındırma, ağlama gibi duygusal zirve sahnelerdeki bazı diyaloglara halk müziği örneklerinden seçkilerin yapılmaması ikilem yaratmıştır. Bununla beraber kameranın kasabaya taşındığında erkeklerin fötr şapkalı, takım elbiseli; kadınların ise şık gece kıyafetli ve süslü takılı bir halde lokale benzer bir ortamda sahnedeki dansözün Adana'nın Yolları Taştan türküsüyle oynatılması bağlam bütünlüğü sergilenmemesine neden olmuştur. Özgün film müziklerinin bulunmadığ 1 ve döşeme tarzıyla müziklerinin seçildiği Sazlı Damın Kahpesi adlı film, mekân itibariyle bir çiftlikte ve köyde geçmesine rağmen seçilen müzikler nedeniyle zaman zaman bu havadan çıkmıştır.

1964 yılında çekilip Murat Sertoğlu'nun eserinden uyarlanan, yapımcıs1 Murat Köseoğlu, yönetmeni Nejat Saydam olan ve oyuncu kadrosunda Tamer Yiğit, Tijen Par, Atıf Kaftan gibi isimler bulunan Dă̆lar Bizimdir: Yörük Efe adlı filmin müzik direktörlüğünü Ahmet Yamacı yapmış; filmdeki türküleri ise Fatma Türkan ve Şahin Gültekin seslendirmiştir. Film, köylülere zulmedip bir cinayet işleyen Mehmet'in hapse girmek yerine cinayetin görgü tanığı Yörük Efe'ye iftira atıp onu hapse düşürmesi ve Efe'nin de intikam almak için hapisten kaçıp dağa çıkmasını" konu edinmiştir (http://www.tsa.org.tr/tr/film/filmgoster/6462/daglarbizimdir).

Filmin jenerik müziği Şu Dalma'dan Geçtin Mi (Hey Gidinin Efesi)adlı Aydın türküsü olmuş ve erkekler tarafından koro olarak seslendirilmiştir. Dügüne hazırlıksırasında davul ve zurnayla Cezayir Oyun Havası çalınmıştır. Divan bağlamayla çalınan ve Münir Nurettin bestesi olan Aheste Çek Kürekleri adlı Türk sanat müziği şarkısının saz bölümü gerilim unsuru olarak bir cenaze sahnesine eşlik etmiştir. Yörük Efe dağda çobanlık yaptığı bir sahnede kaval çalmış; Yörük Efe'yle Feride'nin cilveleşmesi sahnesinde ya da duygusal diyaloglarında curayla şelpe çalınmış (Boğaz Havası Çeşitlemesi); Yörük Efe'nin dağa çıkması ve nişancılığını kanıtlaması sırasında bağlama grubuyla Yağcılar Zeybeği; efelerin kızan paylaşma sahnelerinde Çaktım Çaktım Yanmadı Zeybeği (erkek solo icra); Alanyalı Molla Ahmet Efe'nin ölümünden sonra Molla Ahmet Efe Zeybeği; Yörük Efe ile Feride'nin düğününde bağlama grubu tarafindan Somalı Zeybeği; gelinin at üstünde gitmesi sırasında koro olarak Gökçe De Karga Olaydım (Feridem) adlı İzmir türküsü; Yörük Efe'yle Feride'nin bir gölette yüzme sahnesinde aksiyon unsuru olarak Abacılar Inişi Saatimin Gümüşü (kadın solo icra) adlı 9/8'lik bir türkü; askeri müfrezenin efelerin izini takibi sırasında Kervan adlı Eskişehir'den derlenen ve bağlamayla $F a$ Acemaşiran düzende ${ }^{9}$ çalınan sözsüz halk müziği ezgisi; düşmanın Aydın'ı işgali, tecavüz ve halkı süngüyle öldürme sahneleri sırasında çok sesli Batı orkestrasından ezgiler; düşmanın püskürtülmesi ve zafer görüntülerinin yansıması sahnelerinde Sakarya Marşı ve Eski İzmir Marşı; son olarak da Rüzgar Gibi Nefesi zeybeği bu filme müzik olarak seçilmiştir. Filmde dikkat çekici nokta, kavga, kargaşa, silahlı çatışma gibi şiddet içeren aksiyonlu sahnelerde korno ağırlıklı Batı kökenli bakır nefesli ailesi çalgılarının kullanılmasıdır. Gerilim ve aksiyon unsuru olarak halk müziği dağarcığından ezgi örnekleri sınırlı kalmıştır.

Yukarıda her iki filmde de kullanılan müzikal materyali -bazı sahne bilgileri vererek- listeleme, sözsüz ezgileri (halk müziği veya diğer müzik türlerini) repertuar bilgisi dahilinde belirtme gibi temel yaklaşımlarımızın yanı sıra müzik ve sahne ilişkisi açısından -birkaç sahne özelinde- bir çözümleme yapmak gerekmektedir. Aynı zamanda bu çözümleme, adı geçenfilmlerde seçilen halk müziği ezgilerinin hangi işlevler gözetilerek filme/filmlere yerleştirildiğinin de bir değerlendirmesi olacaktır. Bu doğrultuda sinema ve müzik, sinema ve (geleneksel) kültür, sinema ve seyirci ilişkisi açısından bütüncül işlevsel bir incelemeyi şöyle yapabiliriz:

Dağlar Bizimdir: Yörük Efe adlı filmde - aslında o dönemki çoğu köy filminde de olduğu gibişelpe icrası duyulmaktadır. Bağlamada tezene kullanılmaksızın parmak uçlarını tellere dokunarak/vurarak ses çıkarma esasına dayalı bir icra tekniği olan şelpe, Orta Asya kökenli tarihsel bir arka plana sahiptir.

\footnotetext{
${ }^{8}$ Filmin jeneriğinde müzikleri hazırlayanifadesi kullanılmıştır.

${ }^{9}$ Bağlama öğreniminde önemli bir model olan ve Kervan düzeni olarak da isimlendirilen bu düzende alt tel la, orta tel $r e$, üst tel ise $f a$ seslerine çekilmektedir.
} 
Türkiye'de -bazı bölgelerde değişik işlevlerde örneklerinin görülmesinin yanı sıra- özellikle Teke Bölgesi Yörüklerine özgü müzikal bir karakter kazanmıştır. (Parlak, 1998).

Örnek Sahne 1: Yörük Efe, dă̆da çobanlık yaptı̆̆ bir günde Feride onu gizlice takip eder; ardından kırda dolaşıllar, cilveleşirler ve tekrar koyunların başına gelirler. Feride'nin süt dolu bakır helkesi, güneş altında kaldığından ekşir:

Feride: "Eyvah, süt gokmuş!

Efe: Niye giz?

Feride: Güneşin altında galırsabubam da gokar. Şimdi napcez.

Efe: Ver sen şunu bana.

Yörük Efe ise helkenin içindeki sütü dökerek koyunlardan yenisini să̆mak üzere eğildiği sahnede -şelpe icra tekniğiyle- boğaz havası duyulmaya başlar...

"El ile bağlama çalma geleneğinde bir ezgi türü olan boğaz çalma, Teke yöresine özgü ve üç telli bağlamayla özdeşleşmiş havalardır” (Parlak, 1998, s. 134, 139). Bu sahnede seçilen bir ezgi olan boğaz havası, sinemada sahne gerçekliğini yakalama ve yansıtma, bu gerçekliği mekan, kostüm, ses bütünlüğü içerisinde temsil etme işlevlerinde bulunmuştur. Başka bir deyişle halk yaşamı ekseninde halk ekonomisi ve halk mutfağından (besin, araç-gereç) örnek görüntülerin verildiği bir sahnede, insan ve doğa birlikteliğinden doğan bir müzik türü -sinemaya özgü- bir gerçeklik imaj1 çizmiştir. Bununla beraber doğa ve sanat arasındaki ilişkide gerçekliğe yakının temsili ise bir halk çalgısı (cura) ve bu çalgıyla icra edilen bir müzik türüyle sağlanmıştır. Bu doğrultuda "aşk, sevda ve tabiat konularının işlendiği bir tür" (Parlak, 1998, s. 140) olarak tanımlanan boğaz havaları dağ başı, koyunlar, çimenler, çiçekler içindeki bir sahnede iki sevgilinin arasındaki aşkı geleneksel bir ezgiyle dokumuştur. Böylelikle müzik ve sahne ilişkisi, sinema ve seyirci ilişkisi açısından da işlevsellik ortaya konulmuş; bağlamsal bütünlük yakalanmıştır.

Örnek Sahne 2: Yörük Efe, gece yarısı Feride'nin evine gizlice gittiğinde ona geldiğini haber vermek için cama birkaç taş atar ve Feride'nin dışarı çıkmasını beklerken yine bir şelpe eşliğinde boğaz havalarından bir örnek duyulur...

Feride: Sen damda (hapis) değil miydin?

Efe: Gaçtım, gaçtım.

Feride: Niçin gaçtın? Şimdi zaptiyeler gelecekler seni yakaleyecekler.

Efe: Gayrı beni kimse yakalayameyecek Feride. Canıma tak dedi. Dağa çıkgem. Namlı bir efenin yanında gizanolcem...

Boğaz havası çeşitlemelerinden yine ezgisel kesitlerin sunulduğu bu sahnede ise şelpe tekniği bir gerilim unsuru olarak kullanılmıştır. Başka bir deyişle müzik ve sahne ilişkisi açısından bir halk çalgısı ve onun icra tekniğiyle bağıntılı olarak yaratılan ezgisi gerilim oluşturma, gerilimi sürdürme veya azaltma işlevi doğrultusunda söz konusu sahneye konumlandırılmıştır. Örneğin Yörük Efe'nin cama taş atttğı ve Feride'yi beklediği bir sırada yavaş ve yumuşak bir ezgisel dokuma; Feride'nin camdan çıkıp iki sevgilinin sarılmak için birbirine koşmalarında ise hızlı ve sık ezgisel dokumalar duyulmaktadır. Burada vurgulanması gereken nokta filmdeki gerilim ve aksiyon içeren sahnelerin çoğunda korno ağırlıklı veya başka Batı kökenli çalgının/çalgıların seçilmesidir. $\mathrm{Bu}$ konuda halk müziğinden bütünüyle yararlanılmamıştır. Diğer taraftan şelpe tekniğini kullanarak icra edilen boğaz havalarıyla gerilim yaratma uygulamasının Türk sinemasında -daha önceki filmlerde-başka örneklerinin de olduğu belirtilmelidir. ${ }^{10}$

\footnotetext{
${ }^{10}$ Genelllikle üç telli curayla icra edilen şelpe tekniğininve bu doğrultuda çalınan boğaz havalarının köy temalı filmlerde gerilim unsuru olarak kullanılması örneği, Muzaffer Sarıözen’in görev aldığı -daha önceki- filmlerde de görülmektedir. Dolayısıyla bu yöntemin fikir bakımından-müzik ve sahne ilişkisi açısından- sinemadakiilk
} 
Susuz Yaz $^{11}$ (1963) filminde de benzer ezgisel motifler işlenmiştir. Örnek sahne şöyledir: Hasan ile Osman adındaki iki kardeş tarlalarındaki suyun başında beklemektedir. Bu sırada uzakta bir yerde gizlenen -Osman'ın sevgilisi- Bahar, elindeki bir ayna ile güneş 1şı̆̆ını Osman'ın yüzüne yansıtmakta ve buluşma isteğini bu şekilde şifreledikleri bir yöntemle iletmektedir. Bu sahnede şelpe eşliğinde icra edilen bir ezgi, aksiyon unsuru olarak gizem çözme ve ruhsal devinim sağlama işlevleriyle kullanılır. Bahar'ın aynayla 1şık tuttuktan sonra sazlıkların içine saklanması ve Osman'ın da sazlıkların arasında onu bulmak için verdiği mücadelede ezginin ritmi 5/8'lik ölçüyle artırılarak heyecan sürdürülür. Yine benzer şekilde Osman ile Bahar'ın düğününden sonra bazı gecelerdeki kısa sevişme sahnelerine şelpe eşliğinde bir boğaz havası eşlik etmektedir.(https://www.youtube.com/watch?v=BwB PQIaQG3M).Diğer taraftan bu filmde duyulan ve şelpeyle çalınan boğaz havalarından seçkiler, filmin bütünündeki çoğu sahneye eşlik ettiğinden aşırıya kaçılmasına ve ezgisel tekrarlara düşülmesine neden olmuştur.

1978 yılında Arzu Film tarafından çevrilen, Atıf Yılmaz'ın yönettiği, senaryosu İhsan Yüce'ye ait olan ve oyuncu kadrosunda Kemal Sunal, Şener Şen, İlyas Salman, Adile Naşit gibi isimlerin bulunduğu bir "köy-kasaba güldürüsü olan" (Dorsay, 1989, s. 142) Kibar Feyzo filmi askerden geldikten sonra sevdiği kızla evlenebilmek için başlık parası biriktirmeye çalışan bir köylü gencinin hikayesini ağalık düzeni eleştirisi temelinde ele almıştır. Filmin müziklerini Ahmet Yamacı üstlenmiş; filmde halay havaları ve halay icrasında Antakya Halkevi Folklor Ekibi'nden yararlanılmış ve filmin açılış altyazısında bu kuruma teşekkür edilmiştir.

Filmin jenerik müziği Süt İçtim Dilim Yandı isimli türküdür. Bu türkü Feyzo'nun evlenme izni için Maho Ağa'ya Bilo'dan önce yetişmesini içeren bir aksiyon sahnesini temsil için seçilmiştir. Hareketli sahnelerin hızının yavaşladığı anlarda ise Süt Iç̧tim Dilim Yandı türküsünün ritmi yavaşlatılarak sahneye uyum sağlanmaktadır. Feyzo'nun kayınbabasından Gülo’yu istemek için koşuşturduğu sırada Emmim Kızı (Arabayı Saldık Düze) adlı Afyon türküsü; Feyzo ve Gülo'nun derenin içinde buluşmaları sahnesinde aksiyon unsuru olarak Zeytin Yapră̆ı Yeşil adlı Kilis türküsü; Feyzo'nun ağaçtan atlama sahnesinde Manda Yuva Yapmış Söğüt Dalına (yavaş bir ritimle); Feyzo'nun düğününde davul ve zurnayla Eli Elime Değdi Hem Ben Yandım Ham Kendi adlı Hatay türküsü ve Helvacı Helva adlı Kilis türküsü; Feyzo'nun ağa tarafindan köyden kovulduktan sonra yol kenarında gerdeğe girmesi sırasında Kervan ve Kaşık Havası adlı sözsüz ezgiler; Feyzo'nun köye dönüp başlık parasının taksitini ödeyemedikten sonra bir kaçı̧̧maca sirasında Sinsin Oyun Havası; Feyzo ile Gülo'nun evde buluşma sahnesinde Bülbüller Düğün Eyler; Feyzo'nun başlık parasının taksitini ödeyebilmek için İstanbul'da bir işçi eyleminde ayran dağıtması sırasında Elazı ğ Dik Halayı; köylünün ağaya ayaklanması ve köyü terk etmesi sahnesinde davul ve zurnayla Köroğlu Barl; Feyzo'nunMaho Ağa'y1 öldürmesi sahnesinde Yiğitler Silkinip Ata Binende koçaklaması çalınmıştır. Diğer taraftan konusu Harran'da geçen ama Hatay'da çekilen bu filmde türkülerin çoğunluğu Doğu ve Güneydoğu Anadolu Bölgesi'nden seçilmiştir.

Kibar Feyzo filminde dikkat çeken bir nokta da müzik döşemeciliğiyle beraber filmdeki karakterlere, konuya ve sahneye uygun olarak müzik üstüne söz döşemeciliğinin yapılmasıdır. "Erkekler: Bu düzen kazan karas1/ Ağalık Allah belası/ İkisini birden alası/ Kızlar bize kalası". Kızlar: Bu düzeni nitmeli/ merdivenden itmeli/ Tingır mıngır düşerken Peşine de göbek atmalı"; "Kızlar: Kibar Feyzom niçin niçin", erkekler: "fötürüm var onun için", kızlar: sana bir fötür alalım/ gerdeğe de biz girelim" vb.

uygulayıcısının kim olduğunu tam olarak söyleyemeyiz. Bu hususta doğrudan bir bilgi de bulunmamaktadır. Bu yöntemin fikir bakımındanilk uygulanışında Sarısözen'in ismini düşünmemize karşlık A. Yamacı'nın-kendi deyimiyle- Ankara Radyosu'nda şelpe çalan ilk kişi olması (Alpyıldız, 2018, s. 105),bu tekniğe ve yöre ezgilerine hakim özelliği ve M. Sarısözen'in müzik direktörü olarak görev üstlendiği filmlerde de bağlamasıyla icralarda bulunması sinemadaki bazı filmlerde şelpe tekniğinin belirttiğimiz işleviyle icra edilmesinde Yamacı'nınilk icracı/uygulayıcı olabileceğini düşündürmektedir.

11 Filmin bütününde sözlü bir halk müziği ezgisi olmayıpduygusal,gerilimli ve aksiyonlu sahnelerin çoğu, bağlamayla yapılan kısa açışlarla veya çeşitli kalıp motiflerle ifade edilmiştir.Bununla beraber aksiyon ve gerilimle örülü başka sahnelerde ise -diğer filmlerde olduğu gibi- batı müziği orkestralarına ait çalgılardan/ezgilerden yararlanılmıştır. 
karş1lıklı söylenen maniler söz döşemeciliğine örnek oluşturmasının yanında filme müzikal bir hava katmıştır. Söz döşemeciliği olarak nitelendirdiğimiz bu örneklerde, mani söyleme geleneğindeki karşlberi'lerden hareketle içerik üretimine gidilmiş; karşıllklı mani söylemenin gelenek kültüründeki icra bağlamı sinemaya aktarılmış ve bir film sahnesinde temsil edilmiştir.

$\mathrm{Bu}$ çalışmada çözümlediğimiz filmlerde seçilen halk müziği ezgilerinin hangi işlevler gözetilerek filme/filmlere yerleştirildiğinin bir başka incelemesini ise Osman Özdenkçi'nin Eskişehir yöresinden derlediği Kervan adlı sözsüz ezgi üzerinden yapabiliriz. Daha önce Sarısözen'in müziklerini seçtiği filmlerde de sık sık yer aldığını gördüğümüz ${ }^{12}$ Kervan ezgisi, 2/4'lük bir ölçüde ağır aksak bir şekilde başlayan (duvar saati sesi ritminde) bir özelliktedir. Müzikal yapı, zihinlerde Yörüklerin deve eşliğinde göç edişini (bazen de devenin yürüyüşünü) çağrıştırmaktadır. Yani ritmik yapı itibariyle bir yol(culuk) ezgisi görünümündedir. Bu doğrultuda sinemada Kervan'ın kullanıldığı/seçildiği sahnelerde de çoğunlukla bir yolculuk göze çarpmaktadır. Dağlar Bizimdir: Yörük Efe adlı filmde de askeri müfrezenin efelerin izini takibi sırasında bu ezgi seçilmiştir. Buna karşılık ezginin başlayış kısmıyla askeri müfrezenin yürüyüş temposu ve ardından efelerin bir tepenin ardında gizlenişi arasında (sahneler arası geçişte) bütünlük sağlanamadığı görülmektedir. Kervan ezgisi bu sahneye sıkıştırılmış hissi vermektedir. Kibar Feyzo filminde ise Maho Ağa tarafından köyden kovulan Feyzo'nun sırtındaki dengiyle beraber köyden ayrılırken yürüyüşü sırasında Kervan ezgisi duyulmaya başlanmıştır. Bu sahnede çalıların arkasına gizlenen Gülo'nun Feyzo!, şeklindeki seslenişi ve tekrar gizlenişi ile oluşan heyecan/gizem karşısında Feyzo'nun etrafına bakıp yoluna/yürüyüşüne devam etmesi sırasındaki şaşkınlığını Kervan ezgisi karşılamıştır. Başka deyişle Kervan ezgisinin ağır aksak yapısı iki sevgilinin gizlice buluşmalarını; bu sahnenin ve Kervan'ın ardından çalınan Kaşık Havası ise cinsel birleşmelerini temsil etmiştir. ${ }^{13}$

Diğer taraftan Ahmet Yamacı'nın müzik direktörlüğünü doğrudan üstlenmediği filmler incelendiğinde ise kendi adında kurduğu bir çalg1 topluluğuyla boy göstermesi dikkat çekicidir. 1958'de çekilen Mavi Boncuk filminde müzik direktörlügü üstlenen klarnetçi Şükrü Tunar'ın yanı sıra Ahmet Yamacı Saz Topluluğu filmdeki ezgilere ve özellikle Muzaffer Akgün, Aziz Şenses gibi radyonun halk müziği solistlerine çalgılarıyla eşlik etmiştir. Filmde bazı türkü ve şarkıların seslendirilmesinin yanında geleneksel ezgilere söz döşemeciliği yapılmıştır. Özellikle Türkiye'nin çeşitli illerine kameranın çevrildiği bu filmdeki sahnelerde yöreye has unsurların bazı türkülerin ezgilerine uyarlanarak anlatıldığ görülmektedir. Bu yöntemin koral icracıları ise Ahmet Yamacı Saz Topluluğu'nun elemanları olmuştur. Örneğin kameranın Gaziantep iline çevrildiği bir sahnede Helvacı Helva türküsünün müziği üzerine kurulan "Gazi ismini aldın... (?)/ Şanlı bir şöhret yaptın/ Senle çarpıyor kalbim// Can evimden vuruldum/ Bu güzel şehrinize/ Kara sevdalı oldum/ Âşı̆̆ı hepinize” şeklinde söz varlığı görülmektedir. (Kameranın çeşitli illere yöneltildiği sahnelerde geleneksel bir müziğe yapılan söz döşemeciliği yönteminde, illerin bu müzik eşliğindeki konuşmalı olarak kısa tanıtımından dolayı sözler tam olarak seçilememektedir). Tüm bu bilgilerden görüleceği üzere Ahmet Yamac1, Türk sinemasında kişisel olarak müzik direktörlüğü yaptığı filmler dışında film müziği görevinin başka kişilerce üstlenildiği filmlerde ses ve saz icracısı olarak şahsen boy göstermiş; kendi adındaki halk müziği grubunun katkılarıyla da topluluk anlamında başvurulabilecek bir kaynak kişi olarak görülmüştür. Yamacı'nın İstanbul Radyosu'nda görev yapması ve burada Muzaffer Sarısözen'in kurduğu Yurdun Sesi Korosu'nun şefliğini üstlenmesi onu otorite sahibi yapmış; bu doğrultuda İstanbul merkezli film şirketleri onun bilgi birikiminden yararlanmıştır.

\footnotetext{
${ }^{12}$ Ala Geyik (1959). Bu ezgi, Halil'in ava çıktığı Zeynep'in de onu aramak için peşine düştüğü sahneye müzik olarak seçilmiştir. (Alpyıldız, 2018, s. 293).

${ }^{13}$ Kaynak kişisi Tamburacı Osman Pehlivan olan Anadolu Kaşık Havası'nın o dönemlerde Lambaya Püf De şeklinde Ahmet Gazi Ayhan/Nida Tüfekçi, Urfalı Babi, Barış Manço gibi isimler tarafından çeşitli düzenlemelerinin yapılması, bu ezgi etrafında müzik ve erotizm ilişkisinin kurulduğunu da göstermektedir. A. Yamacı da KibarFeyzo filmindeki bu sahnede Kaşık Havası'nın bu özelliğinden yararlanmıştır.
} 


\section{Ahmet Yamacı'nın Müzikal Kimliğine ve Yeşilçam'da Halk Müziğinin Kullanımına İlişkin Genel Değerlendirmeler}

Ahmet Yamacı'nın ilk filmlerinde enstrümantal olarak çalınan türkülerin ortak özelliği bağlama ailesinin toplu icrasıdır. Filmlerde ritim unsuru olarak -radyo tiyatrosu efektlerinde olduğu gibi- çeşitli yapay seslendirmelerden zaman zaman yararlanılmıştır. Filmin aksiyonu yüksek ya da dramatik unsurların ağır bastığı sahnelerde genellikle klasik Batı müziği çok sesli orkestralarının ezgi örnekleri eşlik etmiştir. Olgunluk dönemi olarak nitelendirebileceğimiz sonraki yıllarda ise bu sahnelerde Batı çalgıları pek duyulmamaktadır. Başka deyişle bağlama ailesinin çeşitli bireylerinden sözsüz icra ya da icra teknikleriyle bu sahneler ifade edilmeye çalışılmıştır. Filmlerde sözlü olarak söylenen türkülerde ise Yurttan Sesler'in icra anlayışı yansıtılmıştır.

Yeşilçam'da A. Yamacı'nın müzik direktörlüğünü üstlendiği filmlerde dikkat çeken önemli bir nokta ise -Muzaffer Sarısözen'in uygulamalarında olduğu gibi- film müziği bestelemek yerine, filmlere uygun sahnelere plak arşivinden seçilen ya da radyonun halk müziği repertuarından sözlü ya da sözsüz/sazlı ezgilerin icra edilip filmlere serpiştirilmesi yönteminin tercih edilmesidir. Başka bir deyişle Türk sinemasında -alg1 ve uygulama bakımından- bir dönem film müziği yapmak, sahnelere uygun eserleri seçerek filme yerleştirmek olarak algılanmış ve buna da müzik döşemeciliği adı verilmiştir. Türk sinemasında halk müziğinin uygulanışında da bu yol izlenmiştir. Türk sinemacılığının gelişmeye başladığı, teknolojik ve içerik olarak birçok yeniliğin ortaya çıtığı, sinemanın özgün kimliğini yakalamaya çalıştığı bir evrede film müzikleri uygulamasında böyle bir alg1 ve yöntemin varlığg bu sürecin doğal yansımaları olarak görülebilir. Aslında bu durumun diğer bir cephesi ise halk müziğinin mevcut özellikleri, durumu (ör. türkü veya gelenek müziği algısı), hazır radyo dağarcığının kullanılabilirliği ve çeşitliliğidir. Bu doğrultuda iletişim teknolojileri ve kültür ilişkileri açısından 1950'li yılların radyo yayıncılığının etkin konumu düşünüldüğünde, Türk sinemasında film müzikleri olarak halk müziğinin kullanımında radyo modelinin örnek alınması ve bunda da radyo şeflerinin/sanatçılarının görev üstlenmesi Yurttan Sesler Korosunun etkilerinin başka sanatsal ve kültürel alanlara bir yansımasını gözler önüne sermektedir. Türk sinemasında film müziklerinin seçiminde müzik döşemeciliği nitelendirmesi ve uygulaması aslında-halk müziği açısından- radyo belleğinin sinemaya taşınmasını/aktarılmasını gerçekleştirmiştir. Bu bağlamda sinemada halk müziği kullanmanın işlevleri -birbirleriyle bağlantılı olarak da -çok boyutlu olarak şöyle değerlendirilebilir:

\section{Film boyutu (sinema sanatı ve teknikleri, sosyal zemin-izleyen/dinleyen/kitle)}

\section{Halk müziği boyutu (temsil ve kültür bağlamları arasındaki geçiş)}

Yedinci sanat dalı olarak nitelendirilen sinema çeşitli türlere ayrılarak, belirli temalar ve konular etrafında renk, 1şık, ses, kostüm, mekân, oyuncu, dil ve müzik gibi unsurlarla kendi gerçekliğini yaratan görsel/kültürel bir etkinliktir. Film yapım süreçleri bakımından filmin ne tür bir insan topluluğuna hitap ettiğinin saptanması; filmde anlatılanın/aktarılanın, dinleyenler/izleyenler üzerindeki etkisinin gözetilmesi önem arz etmektedir. Sinema kuramcısı ve yönetmen Vsevolod Pudovkin'e göre (1966) "belirli bir görüş noktasından alınan ve perdede seyircilere gösterilen her nesne, alıcı önünde hareket etmiş bile olsa, ölü nesnedir" (s.17). Teknik özelliklerin yanında sosyal ve kültürel bağlam bütünlüğünün öneminin vurgulandığı bu ifade doğrultusunda, filmlerdeki müzik unsurunun (seyirciyi) ağlatma, acındırma, heyecanlandırma, coşturma, filmin içine çekme, (onların) geçmişle olan bağlantısını sağlama, aidiyet duygusunu pekiştirme gibi işlevleri filmin hitap ettiği sosyal çevrenin kendi bilindik değerleri (kültürel belleği/kodları) üzerinden gerçekleştirilmesi gerektiğini de ortaya çıkarmaktadır. Başka bir ifadeyle köy temalı ya da konusu itibariyle halk kültürünün işlendiği filmlerde anlamlandırmanın sağlanmasında halk müziğine yer verilmesi "hareketsiz bir seyircinin, alıcı ve etkin bir gözlemciye" (Pudovkin, 1966, s. 8485) dönüş̧ürülmesini sağlanmaktadır. Böylece anlatımı ve görüntüyü desteklemek; duygu bütünlüğünü, kültürel ve algısal sürekliliği oluşturmak; seyircinin özdeşleşmesini sağlamak gibi işlevler sinema teknikleri ile sosyo-kültürel zemin ilişkisi bakımından önemli yöntemler olarak öne çıkmaktadır. Kısaca, 
ilgili filmlerde halk müziğinin kullanımı "müziğin ruhunun görüntünün ruhuyla uyuşması" (Pudovkin, 1966, s. 209) işlevi görmektedir.

İkinci işlev olarak vurgulanması gereken gelenek kültürünün müziği olan türkülerin, teknoloji ile ilişkisi açısından (elektronik) kültür bağlamları arasındaki yolculuğudur. Türkiye'de halk müziğinin alan araştırması bağlamında derlenme projesinin kurumsal açıdan köşe taşı olan Darü'l-Elhan derlemelerinde (1926-1929) canlı performansların kaydedilmesi sürecinde (öncesinde fonograf) gramofon; kaydedilmiş performansların kültürel ekonomik bir ürün olarak işlenmesi ve sunulmasında ise (Columbia) plaklar, halk müziği ile teknoloji ilişkisinin bir ayağını temsil etmektedir. (Alpyıldız, 2019, s. 259). Bununla beraber bu ilişkinin diğer bir ayağı olan radyo ise -daha önce zorunlu sebeplerden dolayı bireysel ve sistemsiz/düzensiz halk müziği örnekleri vermesine karşılık- esas olarak Ankara Devlet Konservatuarı tarafindan gerçekleştirilen derleme gezilerinden ${ }^{14}$ elde edilen materyalin daha profesyonel bir kadro ile (düzenli/sistemli bir şekilde) halk müziği icrasıyla bu süreçte öne çıkmıştır. Aynı zamanda bu durum uygulamalı halkbilimi örneği olması bakımından dikkate değer olmaktadır.

"Elektronik kültür çağının sesli/işitsel bir aracı olan radyonun -uzun y1llar süren egemenliğinin yanında- görsel eksikliğini gideren sinema ise halk müziği ile teknoloji ilişkisinin kurulmasında bir başka basamak olarak kabul edilebilir" (Alpyıldız, 2019, s. 259). Sinemada müzik olarak sözlü ve sözsüz türkülerin yer alması halk müziğine radyodan sonra yeni bir icra bağlamı kazandırmıştır. Başka deyişle radyo belleğinin sinemaya aktarımı/taşınması şeklinde ifade ettiğimiz bu uygulama, halk müziği için yeni bir temsil alanı açmıştır. Sinema ise kendi gerçekçiliğini ve etkileyiciliğini sağlama adına yararlandığı unsurun o dönemki etkin bir icra mekânı olan radyo ile (müzikal kadro ve öğeleriyle) kültür alışverişinde bulunmuştur. "Halk müziğinin yüzyılların süzgecinden geçerek oluşturduğu dağarcığın sınırsızlığı ve kullanılabilirliği; bu kültürel belleğin bir koro özelinde (Yurttan Sesler) ya da koronun geleneğiyle radyo aracılığıyla yaşatılıyor oluşu; ülkede halk müziği konusunda yetkin isimlerin radyo çatısı altında kurumsal görev yürütmesi gibi gerekçe ve şartlar sinema içerisinde -halk müziği kullanımında- radyo modelinin bire bir örnek alınması sonucunu doğurmuştur. Diğer taraftan filmlerdeki halk müziği kullanımı nedeniyle filmlerin öğreticilik işlevi açığa çıkmış; radyodan türkü öğrenmenin yerini sinema almaya başlamıştır. Halk müziği de plak, radyo ve gazino dışında başka bir icra bağlamı kazanmıştır” (Alpyıldız, 2018, s. 296). Sinema ise öğreticilik misyonuyla filmin oyuncu kadrosu ya da türüne göre söz konusu türküleri radyonun sadece işitsel özelliğinin aksine sesli ve görsel olarak da seyirciye sunabilmiştir. Bu doğrultuda bir halk müziği sanatçısı, bazı filmlerde boy gösterdiği ve tanınırlığını sağladığ1 gibi canlı icra ortamı olmayan ama görsel/işitsel içeriğe sahip sinema sayesinde varlık alanı bulmuştur. İşitsel teknoloji ile görüntülü ve sesli teknoloji bağlamının kültürel alışverişi birbirini besleyecek şekilde gelişmiş; halk müziği ise yaşam alanı bulduğu film/filmler içerisinde görsel verilerden oluşan çağrışımları somutlaştırma ve zenginleştirme unsuru olmuştur.

\section{Sonuç}

Tekno-kültürel bir kabul ve geçiş aracı olan sinema, eşiğinden içerisine girdiği kültürü etkileme, biçimlendirme, kültürel ekonomik bir alan oluşturma gibi işlevleri bulunmakta ve bunu çeşitli yollarla gerçekleştirmektedir. Her teknolojik araç ve bu doğrultuda oluşan elektronik kültür ortamı evrensel olduğu kadar ulusal ve yerel karakter de taşımakta; içerik olarak girdiği kabın şeklini almaktadır. İç ve diş dinamiklerin bütüncül bir şekilde değerlendirilmesi gereken bu noktada sinema ise kendi varlığını mensup olduğu yeni sosyo-kültürel bağlamda sürdürmek ve pekiştirmek için malzeme (içerik) olarak gelenek kültüründen yararlanmak durumundadır. (Bu durum, Yeşilçam sinemasında Türk halk müziğinin neden

\footnotetext{
${ }^{14}$ Türkiye'de cumhuriyet döneminde gerçekleştirilen halk müziği derleme çalışmaları için ayrıca bakınız: Elçi, A. (1997). Muzaffer Sarısözen (Hayatı, Eserleri, Çalışmaları), Ankara: Kültür Bakanlı̆̆ı Yayınları; Elçi, A. (2008). Tarihsel Gelişim Bağlamında Türk Halk Müziği Araştırmaları, Milli Folklor, (78), 42; Şenel, S. (1999). Cumhuriyet Dönemi Türk Halk Müziği Araştırmaları. Folklor Edebiyat, (17), 106; Ünlü, C. (2016). Git Zaman Gel Zaman. Pan Yayınc1lı, İstanbul.
} 
yer bulduğunun önemli bir yönünü oluşturmaktadır). Yine bu doğrultuda sinemanın -iletişim teknolojileri veya teknolojik diğer araçlar gibi- resmi veya özel kurumların çeşitli amaçları (örneğin kültür politikaları) doğrultusunda kullanıldığı veya bazı amaçlarla sinemadan yararlanıldığı gözlerden kaçmamaktadır. Diğer taraftan Türk halk müziğinin Yeşilçam'da yer bulması/uygulaması ise öncesinde radyoyla başlayan bir sürecin yeni zemindeki yansımaları olarak kabul edilebilir. Başka bir deyişle gelenek kültürünü temel alan bir hareketin ve bu doğrultudaki çalışmaların teknolojik ürünler/araçlar içerisindeki temsilidir. Böylelikle Türkiye'de halk müziği ile sinema veya sinema ile halk müziği ilişkisinin kurulmasına -ülkede halk müziği konusunda yetkin isimlerin radyoda görev yapması vb. sebeplerden dolay1- radyonun halk müziğ şahsiyetleri/kadrolarının öncülük ettiğini; bu doğrultuda radyo modeli örnek alınarak Muzaffer Sarısözen'in önce radyo yayınlarına daha sonra Yeşilçam'a yerleştirdiği Yurttan Sesler (icra) geleneğini Ahmet Yamacı'nın sürdürdügünü söyleyebiliriz. Diğer taraftan Yeşilçam sineması içerisinde film müziği olgusunun uzun yıllar boyunca filmin temasına, karakterine, sahnelerine repertuardan seçilen müzikleri sahne ve içerik uygunluğu gözeterek filme yerleştirmek anlamında algılandığını; sinema literatürüne müzik döşemeciliği olarak geçen bu yöntemin bir temsilcisinin de Ahmet Yamacı olduğunu belirtebiliriz. Başka deyişle halk müziğinin mevcut yapısı ve diğer şartlar da (anonimlik, örnek model, kullanılabilir hazır dağarcık, kadro vb.) bu müziğin filmde müzik şeklinde kullanımasına olanak sağlamıştır denilebilir. Buna karşılık film müziği kavramı her ne kadar filmin tema ve konusuna uygun olarak görüntülerle bir bütün oluşturma/görüntüyü destekleme işlevinde bulunsa da filme özgü müzik olduğunun altının çizilmesi gerekmektedir. Bu şartlar bakımından Muzaffer Sarısözen'in ve ardından Ahmet Yamacı'nın-müzik insanı olarak- Yeşilçam'daki varlığının/misyonunun Türk sinemasında özgün film müzik besteleme konusunda öne çıkan Nedim Otyam ve Yalçın Tura gibi isimlerden farklı oldukları gerçeği de belirtilmelidir. Sarısözen ve Yamacı, film müziği besteciliği nitelikleri olan veya bu şekilde varlık göstermiş müzisyenler değildir. Dolayısıyla bu kişilerin Yeşilçam'daki görevi ise bu doğrultuda olmayıp Türk sinemasına mevcut materyal ve bilgi birikimleriyle katkı sunmalarıdır. Başka deyişle filmlerin müziklerini seçmeleri ve uygun sahnelere yerleştirmeleridir.

Sonuç olarak Ahmet Yamacı'nın, Yeşilçam'da müzik direktörlüğünü üstlendiği filmlerde, Yurttan Sesler geleneğinden özümsediği radyo modelini sinemaya yerleştirmesi ve halk müziğinin işlerliğine bir radyo şahsiyeti olarak katkı yapması -kendi bağlamsal şartları temelinde-dikkate değer hizmetler olarak öne çıkmaktadır.

\section{Kaynakça}

Ahmet Yamac1. (t.y.). http://www.tsa.org.tr/tr/kisi/kisigoster/1083/ahmet-yamaci adresinden erişildi.

Akgün, H. A. (2009). 2000-2007 yılları arasında Türk sinemasında film müziği kullanımı. (Yüksek lisans tezi). Maltepe Üniversitesi, İstanbul.

Alpyıldız, E. (2018). Yurttan Sesler: Ankara Radyosu'ndan Türkiye'ye açılan pencere. Ankara: Gazi Kitabevi.

Alpyıldız, E. (2019). Dijital kültür ve halk müziği. M. Özdemir (Yay. haz.), Dijital kültür, içinde (s. 257-267). İstanbul: Arı Sanat.

Ataman, N. (Yapımc1), Yüce, İ. (Senarist), Yılmaz, A. (Yönetmen), (1978). Kibar Feyzo. [Film]. 12. 06. 2020 tarihinde https://www.youtube.com/watch ?v=stOXnCPxOws adresinden erişildi.

Beşevli, P. (2002). 1995-2000 yılları arasında yapılan Türk film müziklerinin biçim ve içerik analizi. (Yüksek lisans tezi), Hacettepe Üniversitesi, Ankara.

Birsel, Ö. (Yapımc1), Gürses, M. (Senarist ve Yönetmen). (1956). Sazlı Damın Kahpesi. [Film]. Türkiye. https://www. youtube.com/watch?v=3rIh4yulMF4 adresinden erişildi.

Dağlar Bizimdir. (t.y.). http://www.tsa.org.tr/tr/film/filmgoster/6462/daglar-bizimdir adresinden erişildi.

Dalgın, M. Y. (2011). 1896 ve 1950 yılları arasında Türkiye'de film ve film müziği üretimi. (Yüksek lisans tezi), İstanbul.

Doğan, E. (2009). Sinema filmlerinde izleyicinin etkilenmesinde önemli rol oynayan öğelerden biri olarak film müziği. (Yüksek lisans tezi), İstanbul Üniversitesi, İstanbul.

Dorsay, A. (1989). Sinemamızın umut yılları: 1970-80 arası Türk sinemasına bakışlar. İstanbul: İnkılap Kitabevi.

Duru, N. (Yapımc1), Eyüpoğlu, B. D., (Senarist) ve Erksan, M. (Yönetmen). (1952). Karanlık Dünya, [Film]. Türkiye. https://www. youtube.com/watch? $=\mathrm{VtPY} 1 \mathrm{AX} 7 \mathrm{pSQ}$ adresinden erişildi. 
Erdoğan, İ., Beşevli Solmaz, P. (2005). Sinema ve müzik. Ankara: Erk Yayıncıllk.

Fidan, S. (2017). Asşılık geleneği ve medya endüstrisi: Geleneksel müziğin medyadaki serüveni. Ankara: Grafiker Yayınları.

Hartley, P. (2012). Scoringthereturntohome: Themusicalconstruction of a Turkishpast in new Turkish cinema. Music and theMoving Image, 5(1), 1-23.

Karanlık Dünya: Âşı1k Veysel'i Hayatı. (t.y.). 15.06.2020 tarihinde http://www.sinematurk.com/film/4448-karanlik-dunya-asikveyselin-hayati/ adresinden erişildi.

Konuralp, S. (2004). Film müziği: Tarihçe ve yazılar. İstanbul: Oğlak Yayınevi.

Köseoğlu, M. (Yapımc1), Saydam, N. (Senarist ve Yönetmen). (1964). Dă̆lar Bizimdir. [Film]. Türkiye. https://www.youtube.com/ watch?v=Dnb5T1zWiyc adresinden erişildi.

Metin Erksan. (Yapımc1, Yönetmen). (1963). Susuz Yaz. [Film]. Türkiye. https://www.youtube.com/watch?v=BwBPQIaQG3M adresinden erişildi.

Muzaffer Sarısözen, (t.y.). http://www.sinematurk.com/kisi/3183-muzaffer-sarisozen/ adresinden erişildi.

Onaran, A. Ş. (1981). Muhsin Ertuğrul'un Sineması. Ankara: Kültür Bakanlığı Yayınları.

Özdemir, N. (2008). Medya, kültür ve edebiyat. Ankara: Geleneksel Yayıncılık.

Özgüç, A. (2005). Türlerle Türk sineması, dönemler/modalar/tiplemeler. İstanbul: Dünya Yayınc1lık.

Özgüç, A. (2012). Ansiklopedik Türk filmleri sözlüğü. İstanbul: Horizon İnternational.

Özgül, E. (Yapımc1, Senarist, Yönetmen). (1958). Mavi Boncuk. [Film]. Türkiye. https://www.youtube.com/watch? $\mathrm{v}=\mathrm{oREDFdvDk64}$ adresinden erişildi.

Özön, N. (1968). Türk sineması kronolojisi (1895-1966). Ankara: Bilgi Yayınevi.

Özön, N. (1983). Türk sineması. Cumhuriyet Dönemi Türkiye Ansiklopedisi, (7), 1878-1916. İstanbul: İletişim Yayınları.

Özön, N. (1995). Karagözden sinemaya, Türk sineması ve sorunsalı (I). Ankara: Kitle Yayıncılık.

Parlak, E. (1998). Türkiye’de el ile bağlama çalma geleneği ve çalış teknikleri. (Sanatta Yeterlilik Tezi), İTÜ.

Pekman, C. (2004). Türk sinemasında bir müzik: Tarihçe denemesi. C. Pekman ve B. K1lıçbay (Yay. haz.), Görüntünün müziği müziğin görüntüsü içinde (s. 23-54). İstanbul: Pan Yayıncılık.

Pudovkin, V. I. (1966). Sinemanın temel ilkeleri. (Çev. N. Özön). Ankara: Bilgi Yayınevi.

Sazlı Damın Kahpesi. (t.y.). 11.06.2020 tarihinde http://www.sinematurk.com/film/5634-sazli-damin-kahpesi/ adresinden erişildi.

Scognamillo, G. (1973a). Türk sinemasında köy filmleri. Yedinci Sanat,4, 8-14.

Scognamillo, G. (1973b).Türk sinemasında köy filmleri (2). Yedinci Sanat, 5, 34-39.

Scognamillo, G. (1973c). Türk sinemasında köy filmleri (3). Yedinci Sanat, 6, 38-42.

Scognamillo, G. (2003). Türk sinema tarihi. (2. b.s.). İstanbul: Kabalcı Yayınevi.

Tonks, P. (2006). Film müziği. (Çev. A. Sivas), İstanbul: Es Yayınları. 